\title{
OPTIMIZING BRAND AWARENESS BY USING FACEBOOK ADS AT BINA POTENSI ANAK INDONESIAN SCHOOLS
}

\author{
Muhammad Hilmyansyah ${ }^{1}$, Noviandi ${ }^{2}$ \\ ${ }^{1}$ Fakultas Ilmu Komputer, Universitas Esa Unggul, Jl. Arjuna Utara No.9, Kebon Jeruk, Jakarta Barat, Indonesia, 11510 \\ Email : hilmyansyahm@gmail.com \\ ${ }^{2}$ Fakultas Ilmu Komputer, Universitas Esa Unggul, Jl. Arjuna Utara No.9, Kebon Jeruk, Jakarta Barat, Indonesia, 11510
} Email : noviandi@esaunggul.ac.id

\section{Info Artikel}

\section{Riwayat Artikel:}

Diterima 30 April, 2021

Direvisi 22 June, 2021

Disetujui 22 June, 2021

\section{Kata Kunci:}

Brand Awareness

Digital

Facebook ads

Media Sosial

Pemasaran

\begin{abstract}
The development of social media today makes changes to marketing methods. Marketing using social media is a cheap solution and does not pose a high risk for the users. With social media, it can be used a way to increase brand awareness. An effective digital marketing media is needed to increase brand awareness, one of them is Facebook ads. In the education sector, facebook ads are still rarely used, generally schools use conventional marketing methods, this method has weaknesses, such as: limited scope and inefficient marketing costs. Marketing used conventional methods is considered ineffective, it occur at out by BPAI School in 2019 only $10 \%$ of potential consumers contacted the school. The small number of marketing effectiveness is the influence of the low brand awareness of the BPAI School, therefore innovation is needed in marketing to increase brand awareness, it is by using facebook ads. The results of the implementation of facebook ads at BPAI School for 5 days concluded that facebook ads had significant effect in increasing brand awareness.
\end{abstract}

This is an open access article under the CC BY-SA license.

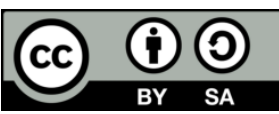

\section{Corresponding Author: \\ Noviandi \\ Fakultas Ilmu Komputer \\ Universitas Esa Unggul \\ Jakarta, Indonesia \\ Email: noviandi@esaunggul.ac.id \\ (C) The Author(s) 2021}

\section{Introduction}

Social media changes the marketing paradigm in the industrial era 4.0. The role of social media makes the relationship between companies/brands and consumers well established, thus give new opportunities to increase brand awareness towards consumers [1]. Marketing using social media, is a marketing technique utilizing social media by creating content [2]. Marketing using social media is an inexpensive solution and has low risk for companies or even small businesses, compared to paying large sums to do marketing on non- 
virtual media. Companies have started to use digital marketing to increase brand awareness in their companies [3].

One of the effective digital marketing methods to increase brand awareness today is Facebook ads. Dehgani \& Tumer, 2015 conducted a study on the effectiveness of facebook ads, where facebook ads provide positive opinions from consumers on brand image and brand equity and have a significant effect on transaction. From these factors, it shows that Facebook ads have significant effect on brand awareness [4]. Bertinus, 2021 in terms of market place, also states that Facebook ads have an effect on increasing brand awareness in significant value of $34.47 \%[5]$.

The use of Facebook ads as a marketing media in education sector is not widely practiced. The results of the observations of researchers in one of the educational institutions in Indonesia, that marketing was done using marketing services and door to door method. In doing marketing, generally schools still use brochures in distributing to various places or conducting workshops at certain event. By using this method, there are weaknesses, such as: the reach of marketing is limited, and marketing operational costs are inefficient. If the school wants to reach more people, it must provide more marketing funds, in order to print more brochures to attend certain workshops held by third parties. In doing marketing, the Indonesian Children's Potential School or Bina Potensi Anak Indonesia (BPAI) used marketing methods by distributing brochures and attending workshops. However, this marketing method is ineffective, as evidenced by marketing using brochures and attending workshops in 2019, only $10 \%$ of potential consumers contacted BPAI School.

The small number of effectiveness of BPAI School's marketing methods is influenced by low level of brand awareness of BPAI School towards consumers. From that problems, it need to make innovation in marketing methods to increase brand awareness to consumers by using digital marketing methods, it is facebook ads. By using Facebook ads, the marketing scope becomes wider, because marketing will be spread through Facebook and Instagram platforms. This statement is also based on the statements [6], [7] that Facebook is the most popular social media and its personalization can be used for marketing methods. Thus, by using facebook ads it is expected to increase the brand awareness of BPAI School to consumers.

\section{Research Methodology}

The steps of the research shown in Figure 1. The researcher first makes observations to find out the target consumers of BPAI School. Observations were made because previous research showed that the age grouping had significant effect on the performance of Facebook ads [8]. Researchers observed 10 parents of BPAI School students. The results of these observations will be reference for researchers in the use of facebook ads. To prove the increase in brand awareness at BPAI School, the researchers will immediately try to do marketing with facebook ads. After marketing is done, researchers will collect data from marketing results on Facebook ads. Data from marketing results will be analyzed to determine whether there is an increase in brand awareness at BPAI School or no. The benchmarks used as reference for increasing brand awareness are reach, impressions, engagement and click-through [9].

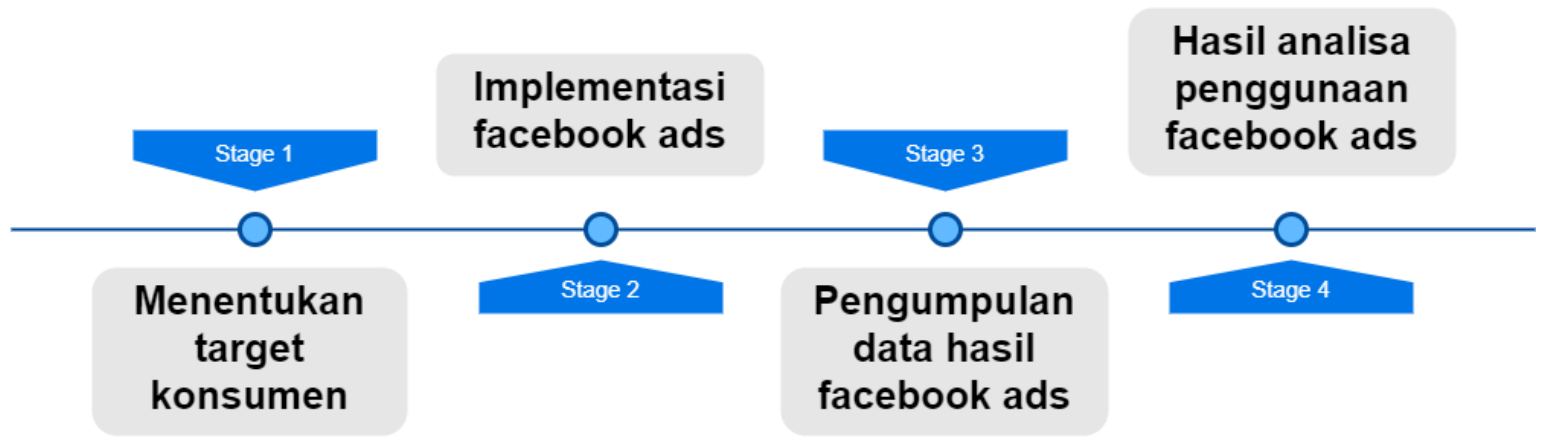

Picture 1. Steps of research 


\section{Results and Discussion}

To prove the increasing in brand awareness by using facebook ads, researchers first determine the observation criteria, in order to determine the target consumers of BPAI School. Chandra marsono conducted research on social media users by grouping the age range of users, the results of the research stated that those aged 25 years and over were included in the adult group [10]. Therefore, the researchers set the observation criteria as shown in Table 1.

Table 1.

Observation Result

\begin{tabular}{cc}
\hline Age & Parents \\
\hline $25-30$ & 0 \\
$31-34$ & 0 \\
$35-40$ & 1 \\
$41-44$ & 3 \\
$45-50$ & 6 \\
\hline
\end{tabular}

Based on the observations in Table 1, the researchers implemented facebook ads at BPAI School for potential consumers with age range of 35-50 years. In the use of facebook ads there is a cost management can adjust according to existing budget, we can control the daily budget for facebook ads which will be deducted every day from the ads balance we have filled. If the Facebook ads budget run out, Facebook will automatically stop the ads [11]. This cost-management is also the upper and lower limits of the results of the user's Facebook ads implementation. If users spend more, then the results from reach, impressions, engagement, and click-through will also be higher. To achieve the same number of reach, impression, engagement, and click-through but without using facebook ads, no conclusive results have been found[12]. In this research, researchers used the lowest-cost method to be implemented at BPAI schools. Here are the results of implementing facebook ads for 5 days.

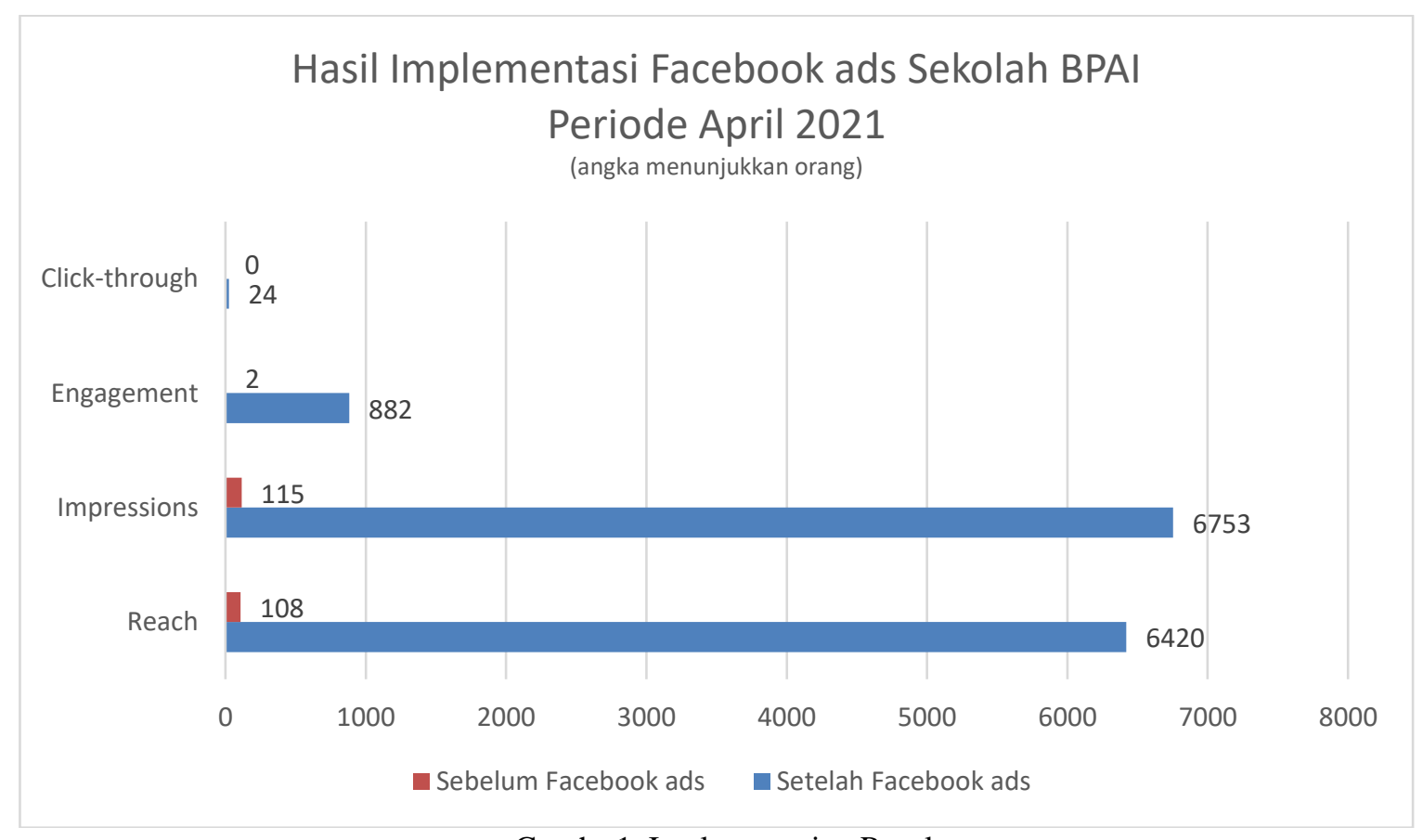

Graphs 1. Implementation Result

\subsection{Reach}

Reach is the number of people who see ads distributed by Facebook ads once, on the same person[13]. Reach is one of the important elements in using Facebook ads, because by increasing reach, there is an effect of increasing brand awareness [14]. According to Sherman \& Smith, 2013 reach is a level of size and strength in social media activity [15]. In social media itself there is a situation where the content we produce spreads so 
widely and quickly, we usually call it "viral"[16]. Under these conditions, reach, engagement, and impressions will automatically increase without the help of Facebook ads. In social media, a content is categorized as viral if the content is shared repeatedly by social media users, and also spreads on users' social media pages [17]. From the results shown in Graph 1, it is clear that facebook ads have significant effect. Even though our content generates high reach numbers, these results are not included in the viral category because these results are numbers achieved from the implementation of facebook ads.

\subsection{Impressions}

Impressions is the number of times of user's screen[18]. Users see the ads twice or more can also be counted into impressions. From the implementation results in Graph 1, we can see that the results of reach and impressions are different, if the number of impressions exceeds the reach value, it indicates that the audience sees our content repeatedly. The higher the impressions obtained, the more people who are familiar with the brand. In this research, BPAI School had impressions that were previously low, but after implementing facebook ads, BPAI School impressions experienced significant increase, according to Allen Finn, 2017 a situation like this is good thing, because we have an active audience, so it is more frequent we create content, then they get to know our brand more so that the opportunity to have many audience[19].

\subsection{Engagement}

Engagement is the total interaction of users towards our content. The interaction can be in the form of like, comment, click-through, or share [20]. When a user sees our ads and likes, or comments, that interaction can be counted as engagement. High engagement values can make social media users find our content from the search \& explore feature or the timeline, this feature can display our content without using ads. There are various ways to increase engagement, it is posting content at optimal hours and using hashtags[21]. BPAI School has obtained the results of the optimal hour analysis on its account, which is from 9 am to 9 pm. We can see the results of the analysis on the school's account in the insights section where this section provides the results of analyzes regarding our account, then the content on BPAI School account has also used hashtags related to schools as a way to increase reach and engagement. These two things also help BPAI School when implementing facebook ads, so that it makes the results of the implementation of facebook ads more optimal.

\subsection{Click-through}

Click-through is the number of clicks on the link displayed on BPAI School advertisement[22]. The results of click-through on facebook ads affect the increase in total of likes on the distributed ads. However, clickthrough does not guarantee the effectiveness of the intended audience, therefore before using Facebook ads, it is very important for every Facebook Ads user to determine their audience [23]. In this research, click-through is a link leads directly to BPAI School whatsapp. From the data has been collected by researchers there are 24 people who click on BPAI School advertisement. However, after being confirmed to BPAI School admin, the admin admitted that he did not receive whatsapp during the time shown ads. According to the researcher, the biggest possibility is the users who click do not send messages directly to the admin, but only see whatsapp number used by BPAI School.

\section{Conclusion}

Social media provides a new color in marketing, because social media offers an interactive relationship between marketers and users [24]. Internet users in Indonesia spend more than 7 hours to access the internet, one of them is to access social media [25]. Based on these data, marketing using social media becomes a new opportunity for brands/companies to market their products.

The use of Facebook ads as marketing media is proven to increase brand awareness of a brand/company. The results of the implementation of facebook ads at BPAI schools conducted by researchers for 5 days can conclude that facebook ads have significant effect on brand awareness, we can see from the results of reach, impressions, engagement and click-throughs obtained after implementing facebook ads showing significant development rates.

The results of this research further strengthen that facebook ads have an effect on increasing brand awareness, this is in accordance with research conducted by Dehgani \& Tumer, 2015, and Bertinus, 2021, which gave similar conclusions. However, according to the researcher, to get conversion results from using facebook ads, the school must implement facebook ads continuously in order to get the desired conversion results. The result of the conversion is the register of new students to BPAI School. By implementing facebook ads continuously, BPAI School's brand awareness will continue to increase, with increasing brand awareness, the possibility for new students to enter BPAI School will increase. 


\section{Acknowledgement}

I say thank to my lecturer, Mr. Noviandi, who has taken the time and shared his knowledge with me as correspondent in this journal. I also thank to the previous researchers so I was able to complete this research.

\section{References}

[1] C. Media, "Social Networking Goes Global," 2009. https://www.comscore.com/Insights/PressReleases/2007/07/Social-Networking-Goes-Global.

[2] S. Singh, Shiv dan Diamond, Social Media Marketing For Dummies, 3rd ed. Canada: John Wiley \& Sons, Inc., 2015.

[3] R. Johns and B. Perrott, "The impact of internet banking on business-customer relationships (are you being selfserved?),” Int. J. Bank Mark., vol. 26, no. 7, pp. 465-482, 2008, doi: 10.1108/02652320810913846.

[4] M. Dehghani and M. Tumer, "A research on effectiveness of Facebook advertising on enhancing purchase intention of consumers," Comput. Human Behav., vol. 49, pp. 597-600, 2015, doi: 10.1016/j.chb.2015.03.051.

[5] B. Sijabat, "Analisis Keputusan Membeli Berbasis Brand Awareness sebagai Impak Google Ads dan Facebook Ads (Kajian Pelanggan Lazada)," Syntax Idea, vol. 3, no. 3, p. 444, 2021, doi: 10.36418/syntax-idea.v3i3.1060.

[6] D. G. Taylor, J. E. Lewin, and D. Strutton, "Friends, fans, and followers: Do ads work on social networks? How gender and age shape receptivity," J. Advert. Res., vol. 51, no. 1, pp. 258-275, 2011, doi: 10.2501/JAR-51-1258-275.

[7] S. Barokah, O. A. D. Wulandari, M. T. Sari, and I. F. Yuditama, "Optimalisasi Digital Marketing melalui Facebook Ads di Kelurahan Purwanegara,” J. Abdimas BSI J. Pengabdi. Kpd. Masy., vol. 4, no. 1, pp. 17-22, 2021, doi: 10.31294/jabdimas.v4i1.7085.

[8] B. J. Jansen, K. Moore, and S. Carman, "Evaluating the performance of demographic targeting using gender in sponsored search,” Inf. Process. Manag., vol. 49, no. 1, pp. 286-302, 2013, doi: 10.1016/j.ipm.2012.06.001.

[9] Redcomm, "Mengukur brand awareness campaign gampang kok," 2021.

https://redcomm.co.id/knowledges/mengukur-brand-awareness-campaign-gampang-kok.

[10] B. Susilo, "Pemasaran Digital: Segmentasi Demografi Pengguna Media Sosial di Kota Pontianak," Eksplora Inform., vol. 8, no. 1, p. 69, 2018, doi: 10.30864/eksplora.v8i1.163.

[11] Facebook, "How much Facebook ads cost," 2021. https://www.facebook.com/business/ads/pricing (accessed Apr. 30, 2021).

[12] Tikno, "Measuring performance of facebook advertising based on media used: A case study on online shops in Indonesia," Procedia Comput. Sci., vol. 111, pp. 105-112, 2017, doi: 10.1016/j.procs.2017.06.016.

[13] Facebook, "Reach,” 2021. https://www.facebook.com/business/help/710746785663278 (accessed Apr. 25, 2021).

[14] N. Hidayah, L. E. Putri, and S. W. D. Kusuma, "Instagram Marketing Engagement di Wana Wisata Ranca Upas Kabupaten Bandung," Khasanah Ilmu-Jurnal Pariwisata dan Budaya, vol. 11, no. 2, pp. 92-100, 2020, doi: 10.31294/khi.v11i2.7623.

[15] A. S. Danielle Elliott Smith, Social Media Engagement For Dummies, 1st ed. Canada: John Wiley \& Sons, Inc, 2013.

[16] L. Agustina, "Viralitas konten di media sosial," Maj. Semi Ilm. Pop. Komun. Massa, vol. 1, no. 2, pp. 149-160, 2020.

[17] A. Deza and D. Parikh, "Understanding image virality," Proc. IEEE Comput. Soc. Conf. Comput. Vis. Pattern Recognit., vol. 07-12-June-2015, pp. 1818-1826, 2015, doi: 10.1109/CVPR.2015.7298791.

[18] Facebook, "Impressions," 2021. https://www.facebook.com/business/help/675615482516035 (accessed Apr. 25, 2021).

[19] A. Finn, "The Real Effect of Running a Facebook Ad Campaign in 5 Charts," 2017. https://www.wordstream.com/blog/ws/2017/03/28/facebook-ad-campaign-data (accessed Apr. 30, 2021).

[20] Facebook, "Post Engagement," 2021. https://www.facebook.com/business/help/735720159834389 (accessed Apr. 25, 2021).

[21] Redcomm, "MENINGKATKAN ENGAGEMENT DI INSTAGRAM, INI CARA TERBAIK SESUAI ALGORITMA INSTAGRAM," 2021. https://redcomm.co.id/knowledges/meningkatkan-engagement-diinstagram-ini-cara-terbaik-sesuai-algoritma-instagram (accessed Apr. 30, 2021).

[22] Facebook, "Link Clicks," 2021. https://www.facebook.com/business/help/659185130844708 (accessed Apr. 25, 2021).

[23] P. P. Radovan Bačík, Richard Fedorko, Lukáš Kakalejčík, "The Importance of Facebook Ads in Terms of Online Promotion,” J. Appl. Econ. Sci., vol. X, no. 5, pp. 677-683, 2015, [Online]. Available: https://www.ceeol.com/search/article-detail?id=537100.

[24] H. Logan, K., Bright, L.F. and Gangadharbatla, "Facebook versus television: advertising value perceptions among females," J. Res. Interact. Mark., vol. 6, no. 3, pp. 164-179, 2012, doi: https://doi.org/10.1108/17505931211274651.

[25] Simon Kemp, "DIGITAL 2020: GLOBAL DIGITAL OVERVIEW,” 2020. https://datareportal.com/reports/digital-2020-global-digital-overview (accessed Apr. 30, 2021). 